\title{
The Role of Business Models in Finnish Construction Companies
}

Aki Pekuri, Laura Pekuri and Harri Haapasalo, (University of Oulu, Finland)

\begin{abstract}
Business models are seen as an essential part of successful businesses as they define the way companies create value for their customers and subsequently make profit from their operations. A good business model has a potential to separate a company from its competitors by creating a competitive advantage. The purpose of this research is to explore how managers understand and deploy the business model concept in construction. For this, eight experienced managers have been interviewed and their answers have been analysed using the theoretical aspects of business models as a reference. In the interviews, managers deployed business model concept very differently than what is accustomed in practice and in academia; they relate these models to different project delivery and contract structures or to companies' business segments rather than to analysing how their companies provide value for customers in the selected markets. The results of the interviews indicate that the managers in construction do neither understand the concept properly nor exploit any similar value creation analysis in their business. The interviewees had significant problems describing their companies' business models and value creation logic, pointing out the lack of analysis and understanding of customer values and needs in the project delivery process. This may be one of the overtones of the persistent client dissatisfaction in the construction industry.
\end{abstract}

Keywords: Business models, Value creation, Business development, Competitive advantage, Strategy

\section{Introduction}

Business models - in other sectors a widely used managerial practice for designing, comparing and analysing an organisation's value creation logic - are a less discussed and researched concept in the field of construction. Current literature sees a business model as an essential part of successful business, as its main purpose is to separate a company from others and to give it an advantage over its competitors (Johnson et al. 2008; Teece 2010). A good business model defines the way a company operates, how it creates value for its customers and how it captures value from its operations to make a profit (Magretta 2002; Morris et al. 2005; Suikki et al. 2006; Casadesus-Masanell \& Ricart 2011). Thus, it forces managers to think about their business and how it works as a whole. In other words, how different elements of a business model create synergies together. Recent developments in this field of research have also led the creation of visual representations of business models, resulting in a better understanding of different business logics and a position where business models are used as an effective management tool to communicate and execute strategy (Osterwalder \& Pigneur 2009; Pekuri et al. forthcoming).

The construction industry has begun to see exceptional innovation in the offerings, delivery systems and overall operating philosophies of some construction companies. For example, IKEA Houses and Toyota Homes may well revolutionise the family house business with their cost-efficient and fast-delivered modular houses, or the hotel chain citizenM with their compact and prefabricated accommodation facilities; these represent a combination of product and process innovation. In California, companies like Herrero Builders Inc. have an organisational philosophy by which they create value for customers through intense 
collaboration, integrated project deliveries and adopted lean practices. This development puts pressure on traditional construction companies, urging them to sharpen their competitive edge beyond price-related issues. But whether it is this or some other issue that triggers the change, finding a new competitive edge should begin with the critical scrutiny of one's own way of doing things - namely, the business model.

The aim of this research is to explore the way the business model concept is understood and utilised in the Finnish construction industry. This will hopefully shed some light on why the vast majority of construction companies do not seem to differentiate from each other. Proper exploitation of business model thinking in the management of a company necessitates managers to think about the way they create value for their customers. Could it be that this kind of deep analysis of value creation systems has resulted in seemingly similar outcomes, or is it that this kind of comprehensive analysis is lacking altogether? The specific research question this paper aims to address is:

- How do managers in construction understand and deploy the concept of the business model?

The research is focused on Finnish construction companies, who typically serve as a main contractor in construction projects; thus, a vast number of construction actors, e.g. design firms and consultants, are not within the scope of this study. The research seeks to develop an understanding between researchers and construction practitioners. Even though the current business model literature is still somewhat scattered in terms of what specific elements constitute a business model or how it is should be defined and presented, it is unanimous in that all of its aspects are integrated into value creation. The research question is addressed by interviews that explore how managers in construction understand the concept of the business model and whether they associate it with the analysis of value creation.

\section{The Business Model Concept}

\section{Focus in Value Creation}

The business model concept builds upon central ideas in the field of business strategy and its associated theoretical traditions (Headman \& Kalling 2003; Morris et al. 2005). Literature on business models attempts to draw insight from different schools of thought, such as Porter's $(1980,1996)$ market-based view on competition and strategic positioning and the resource-based view, which conceptualises a firm as a bundle of resources (Prahalad \& Hamel 1990; Barney 1991). The difference is that whereas strategy emphasises competition, business models build more on the creation of value for customers (Morris et al. 2005) while still being aligned with the specific strategy, structures and culture of the focal firm (Casadesus-Masanell \& Ricart 2010; Wikström et al. 2010). Hence, a business model can be described as the way a company operationalises its strategy to concrete business activities or initiatives (Chesbrough \& Rosenbloom 2002; Casadesus-Masanell \& Ricart 2010). In addition to its ties with strategy, business models relate to the value chain concept (Porter 1985) and the extended notions of value systems such as the choice of value configuration presented by Stabell and Fjeldstad (1998).

One of the first authors to discuss the concept of business models was Timmers (1998). He identified multiple emerging Internet-based business models and mapped them along two dimensions - their degree of innovation and their extent of functional integration. He concluded that these business models were only feasible because of the openness and connectivity of the Internet. Indeed, business models have often been used in generating and articulating plans to make money through innovations or certain technologies. Chesbrough and Rosenbloom (2002), for example, discussed the role of business models in capturing value from innovations at Xerox. They highlighted the point that it is not enough to

Pekuri, A et al (2013) 'The role of business models in Finnish construction companies', Australasian Journal of Construction Economics and Building, 13 (3) 13-23 
merely create value for customers; it is important to also find the right revenue models to capture value, i.e. to make profit. This indicates the systematic nature of the business model - it is not about details of isolated elements, but how the elements are interconnected and how they reinforce each other to form a well-functioning whole.

\section{Key Elements as a Common Language}

The term 'business model' has steadily gained widespread popularity since the 1990s, when business models and the changing firm boundaries were discussed in the context of the Internet (Afuah \& Tucci 2000; Afuah 2003; Osterwalder 2004; Burkhart et al. 2011). In recent years, the business model concept has been used as a general construct explaining how a firm interacts with suppliers, customers and partners (Zott \& Amit 2007). Currently, there is a lack of consensus in regard to what constitutes a business model and how it should be defined, classified or represented among business model researchers (Osterwalder 2004; Morris et al. 2005; Shafer et al. 2005; Nenonen \& Storbacka 2010). This lack of consensus has been attributed to the fact that the concept draws from and integrates a wide range of academic and practical disciplines (Chesbrough \& Rosenbloom 2002; Pateli \& Giaglis 2004; Shafer et al. 2005).

As said, there are multiple studies comparing, summarising and integrating the elements that a business model should contain. Morris et al. (2005), for example, identified 24 different elements from 19 sources, while Shafer et al. (2005) studied 12 different definitions to find 42 different business model elements, categorising them into four groups: strategic choices, value network, create value and capture value. In addition, several others have presented their own frameworks for analysing and conceptualising business models (see Hedman \& Kalling 2003; Johnson et al. 2008; Kujala et al. 2010; Wikström et al. 2010; Mutka \& Aaltonen 2013). Osterwalder's (2004) comprehensive study proposes a business model framework containing the following elements: value proposition, target customer, distribution channel, customer relationship, value configuration, capability, partnership, cost structure and revenue model. These elements were slightly adjusted by Osterwalder and Pigneur (2009), who created the visual management tool - the business model canvas - for the design and description of business models.

Although most of the studies propose different definitions for the business model, it is possible to identify certain similarities that appear in most of them (Suikki et al. 2006; Nenonen \& Storbacka 2010; Pekuri et al. forthcoming). First, the majority of business model definitions include customer value creation as one of their core elements. Second, earning logic is also mentioned in various business model definitions. Third, many business model definitions discuss the value network of a firm, illuminating the relationships that a firm has with various actors in its value network. Finally, the resources and capabilities that a firm has and the types of strategic decisions, choices or principles that it makes are also often included in business model definitions (Nenonen \& Storbacka 2010). The most important thing regarding the elements of business models is that they provide a common language for those who discuss business models (for which everyone usually has a different definition and understanding). Osterwalder (2004) and Osterwalder and Pigneur (2009) provide a detailed framework for business model analysis and description, but in this research, the following three elements are adequate to describe the essence of business models:

- 'Value creation system' consists of the most important assets, competences, suppliers and key partnerships that are required to develop and produce offerings that will deliver the created value to customers (Osterwalder \& Pigneur 2009).

- 'Offering' refers to the output of the value creation system. With the offering, companies aim to solve customers' problems and satisfy their needs; thus, the goal of any offering is to provide value to a specific customer segment (Osterwalder \& Pigneur 2009). 
- 'Revenue model' is a blueprint that defines how the company creates value for itself while providing value to the customers (Johnson et al. 2008). Revenue generation measures a company's ability to translate its value proposition into revenue streams (Osterwalder 2004) and to cover its costs.

\section{The Business Model as a Source of Competitive Advantage}

Successful firms create substantial value by doing things in ways that differentiate them from the competition, e.g. by developing core competencies, capabilities and positional advantages that are different from those of competitors. The viability of for-profit companies is also tied to the way they capture value and resultantly generate profit. In this regard, the terms 'creating value' and 'capturing value' reflect the two fundamental functions that all organisations must perform to remain viable over an extended period of time (Shafer et al. 2005).

The literature on business models is filled with great stories of how the right business model may change the fate of virtually anything. Magretta (2002) even defined business models as stories that explain how enterprises work. She went on to present a century-old success story of American Express's introduction of travel cheque - which turned the normal cycle of debt and risk on its head while having all the elements of a good business model from value creation to its capture - pointing out that every viable organisation is built on a sound business model regardless of whether this model is articulated or not. Hamel (2000) as well as Osterwalder and Pigneur (2009) described multiple business models using well-known companies to emphasise the importance of business model innovation. Hamel (2000) argued that business model innovation is the only way to avoid competition even temporarily, while Johnson et al. (2008) reported that business model innovation in general is becoming even more important for success than product or service innovation. If a business model is sufficiently differentiated to meet particular customer needs and is hard to replicate, it can result in a competitive advantage (Morris et al. 2005; Teece 2010).

The problem with innovating business models is that only a few managers understand their companies' current business models well enough to develop them further or to change them at the right time (Linder \& Cantrell 2000; Johnson et al. 2008). This is where a proper business model analysis using a set of defined business model elements is useful. The defined elements give managers a common language to discuss, design and compare business elements, and most importantly, to analyse the interdependencies between the elements. According to Morris et al. (2005), a business model should be both internally and externally consistent. Internal consistency means fitness between different elements (as they affect and are affected by one another), while external consistency is how the choices in business model elements fit into the external environment.

The variety of business model descriptions found from various kinds of sources demonstrate the fact that business models are no longer discussed and used exclusively in the context of e-business; instead, the concept has been transformed into a management tool that is currently used in all kinds of organisations to create a competitive advantage. In general, business models can concretely be used to capture, visualise, understand, communicate and share the business logic of a firm. They can also be applied in measuring, observing and comparing a company to others and to improve management by ameliorating the design, planning, changing and implementation of business models (Osterwalder 2004).

\section{Research Approach}

This is a qualitative research with data consisting of eight face-to-face, semi-structured interviews conducted in Northern Finland between February and March 2013. The research follows the interpretive research tradition. The interviewees were asked about their understanding and use of the concept of the business model in their companies and their

Pekuri, A et al (2013) 'The role of business models in Finnish construction companies', Australasian Journal of Construction Economics and Building, 13 (3) 13-23 
answers were analysed via the aforementioned theoretical aspects. The interviews provide a basis for understanding the current role of business models in construction companies. At the same time, they provide the basis for analysing how construction companies could benefit from introducing business model thinking into their management. The interviewees were not given a definition or structure of a business model or its suggested elements; instead, they were asked to answer the questions according to their own conception of the term and to describe the operating logic of their company.

All of the interviewees had more than 15 years of experience in the construction industry, working as chief executives or regional managers in their companies. Interviewees came from three large, two medium and three small construction companies. They were selected from the top of the organisational hierarchy as this position requires the most comprehensive view of a company's business activities. The companies were selected from the same geographical region so that their competitive environment would be similar. The interviews lasted for 1-2 hours each and all of them were recorded and transcribed. Additionally, other sources of material such as company websites were also used to formulate an understanding of the logic by which these construction companies operate.

\section{The Role of Business Models in the Construction Companies}

Table 1 depicts the business models of the companies as perceived by the interviewees. Along with the formation of business model descriptions, some interpretation by the authors was needed because the interviewees did not have any systematic way of structuring or describing the answers about their business models.

\begin{tabular}{|c|c|}
\hline & Description of the Business Models of Studied Companies \\
\hline $\begin{array}{l}\text { Company } 1 \text { : } \\
\text { A regional business } \\
\text { unit of a large } \\
\text { international } \\
\text { construction group }\end{array}$ & $\begin{array}{l}\text { Operates regionally to understand the local circumstances and the special } \\
\text { characteristics of economic and population structures as well as to take into } \\
\text { account customers' needs in planning and realising construction. Focuses } \\
\text { on project development where it can deploy its business knowledge for } \\
\text { customers' benefit. Works in challenging circumstances. }\end{array}$ \\
\hline $\begin{array}{l}\text { Company 2: } \\
\text { A regional business } \\
\text { unit of a large } \\
\text { international } \\
\text { construction and } \\
\text { project development } \\
\text { company }\end{array}$ & $\begin{array}{l}\text { A pioneer and specialist in project management contracts. The competitive } \\
\text { edge is based on an approach that combines strong project development } \\
\text { expertise and construction into a consistent and flexible process that allows } \\
\text { client participation. Key competences include understanding future trends, } \\
\text { systematic plot acquisition and project management in general. Operates in } \\
\text { big cities in Russia, Finnish metropolitan areas and other domestic growth } \\
\text { centres. }\end{array}$ \\
\hline $\begin{array}{l}\text { Company } 3 \text { : } \\
\text { A large, domestically- } \\
\text { operating construction } \\
\text { company }\end{array}$ & $\begin{array}{l}\text { Focus in own development or turnkey projects where the company can } \\
\text { assume overall responsibility of the projects. Contracting services offered for } \\
\text { stable and professional customers, such as companies, investors, } \\
\text { municipalities and cities and in the field of expertise (i.e. nurseries). }\end{array}$ \\
\hline $\begin{array}{l}\text { Company 4: } \\
\text { A medium-sized and } \\
\text { domestically- } \\
\text { operating construction } \\
\text { contracting company }\end{array}$ & $\begin{array}{l}\text { Experienced industrial builder with innate will to concentrate on complex and } \\
\text { unique projects. A pure contractor that builds and maintains close } \\
\text { relationships with its customers. The current focus in industrial building is on } \\
\text { mining projects; its other specialty is hospitals. Serves its long-time industrial } \\
\text { customers in the paper and metal industries by executing all kinds of } \\
\text { projects as well as offering cost-based maintenance services. }\end{array}$ \\
\hline $\begin{array}{l}\text { Company } 5 \text { : } \\
\text { A medium-sized and } \\
\text { regional construction } \\
\text { company }\end{array}$ & $\begin{array}{l}\text { Aims to take on the overall responsibility for projects by operating close to its } \\
\text { customers. Acts in multiple fields of operations to grow while in the future the } \\
\text { focus will be on development projects. All kinds of sources are exploited to } \\
\text { find new profitable projects. }\end{array}$ \\
\hline
\end{tabular}

Pekuri, A et al (2013) 'The role of business models in Finnish construction companies', Australasian Journal of Construction Economics and Building, 13 (3) 13-23 
Table 1 con't

\begin{tabular}{|l|l|}
\hline $\begin{array}{l}\text { Company 6: } \\
\text { A small, locally- } \\
\text { operating construction } \\
\text { company }\end{array}$ & $\begin{array}{l}\text { Aim is to master all kinds of construction bar infrastructure within the limited } \\
\text { geographical sphere of operations. Aims at turnkey construction where it can } \\
\text { use local knowledge in land acquisition. Industrial building is a base for } \\
\text { business and housing is used to level market fluctuations. Invests in training } \\
\text { its long-term workers and modern equipment to participate in industrial } \\
\text { projects. }\end{array}$ \\
\hline $\begin{array}{l}\text { A small, locally- } \\
\text { operating construction } \\
\text { company }\end{array}$ & $\begin{array}{l}\text { Builds low-rise houses on rented land. Targets projects that last over a year } \\
\text { to utilise its capacity efficiently. Uses well-known designers to increase its } \\
\text { chance of getting desired pieces of land. Increases its efficiency by using } \\
\text { standardised flat types and by targeting certain areas for synergies in } \\
\text { logistics and marketing. }\end{array}$ \\
\hline $\begin{array}{l}\text { Company 8: } \\
\text { A small, locally- } \\
\text { operating construction } \\
\text { contracting company }\end{array}$ & $\begin{array}{l}\text { Aims to operate in complex, unique and slightly inconvenient projects in } \\
\text { order to learn from them to deepen its expertise. Specialises in school and } \\
\text { care facility renovations. Competitive edge is in specialist expertise and in } \\
\text { exploiting its leaner cost structure against construction groups. Targets } \\
\text { projects over a certain size to leave out the smallest competing firms that } \\
\text { have no financial resources. }\end{array}$ \\
\hline
\end{tabular}

Table 1 Descriptions of the business models

As displayed in Table 1, the interviewed companies are varied in terms of their size and business models. Despite the apparent variety, we encountered significant challenges in an attempt to identify any truly unique and distinctive characteristics in these models that would give these companies a competitive advantage, which Barney (1991, p. 102) defined as 'a value creating strategy not simultaneously being implemented by any current or potential competitors'. Instead, the differences stem from their diversification; the bigger the company, the more diversified its portfolio of businesses (Table 2).

\begin{tabular}{|c|c|c|c|c|c|c|c|}
\hline \multirow[b]{2}{*}{$\begin{array}{l}\text { Field of } \\
\text { operation }\end{array}$} & \multicolumn{3}{|c|}{$\begin{array}{l}\text { Development for a client } \\
\text { (e.g. design-build) }\end{array}$} & \multirow{2}{*}{$\begin{array}{c}\text { Own } \\
\text { development } \\
\text { Residential } \\
\text { units }\end{array}$} & \multicolumn{3}{|c|}{$\begin{array}{l}\text { Contracting of construction } \\
\text { (e.g. design-bid-build) }\end{array}$} \\
\hline & $\begin{array}{l}\text { Business } \\
\text { premises }\end{array}$ & $\begin{array}{c}\text { Commercial } \\
\text { buildings }\end{array}$ & $\begin{array}{c}\text { Nursery } \\
\text { schools and } \\
\text { nursing } \\
\text { homes }\end{array}$ & & $\begin{array}{l}\text { Industrial } \\
\text { buildings }\end{array}$ & $\begin{array}{c}\text { Renovation } \\
\text { construction }\end{array}$ & $\begin{array}{l}\text { Infra- } \\
\text { structure }\end{array}$ \\
\hline $\begin{array}{c}\text { Company } \\
1:\end{array}$ & $x$ & & & $x$ & $x$ & $x$ & \\
\hline $\begin{array}{c}\text { Company } \\
2 \text { : }\end{array}$ & $x$ & $x$ & & $x$ & & & $x$ \\
\hline $\begin{array}{c}\text { Company } \\
3:\end{array}$ & & & $x$ & $x$ & & & \\
\hline $\begin{array}{c}\text { Company } \\
4:\end{array}$ & & & & & $x$ & $x$ & \\
\hline $\begin{array}{c}\text { Company } \\
5:\end{array}$ & & $x$ & & $x$ & & & \\
\hline $\begin{array}{c}\text { Company } \\
6:\end{array}$ & & $x$ & & $x$ & $x$ & $x$ & \\
\hline $\begin{array}{c}\text { Company } \\
7 \text { : }\end{array}$ & & & & $x$ & & & \\
\hline $\begin{array}{c}\text { Company } \\
8:\end{array}$ & & & & & & $x$ & \\
\hline
\end{tabular}

Table 2 The construction companies' fields of operations

\section{Common Language}

Based on the interviews, it is clear that 'business model' as a term is rarely used in these construction companies, while as a concept or a management tool it is used quite differently

Pekuri, A et al (2013) 'The role of business models in Finnish construction companies', Australasian Journal of Construction Economics and Building, 13 (3) 13-23 
than what is typical in other sectors or within the literature. Questions like, 'Do you know the concept of business models?', 'Do you use the word?', 'How do you define a business model?', 'What elements compose it?' and 'How and why are such models described and used?' produced a wide variety of answers. Interviewees also had opposing views as to whether there should be one or several business models at different levels of an organisation (e.g. at the level of a firm, business unit, for each field of operation or even for each independent project). Every manager seemed to think that he or she knew what business models were, but the reality was that there were as many definitions and explanations as there were interviewed managers.

Although there was a partial conception of a business model's function as a means for creating a competitive advantage via differentiation, more emphasis was put on using it to set objectives and acquire work. The minimum requirement should be to identify the value a company is creating for its customers in the chosen markets or to explain the basis for its long-term existence and profit generation. Instead, the discussions turned to fields of operations, business segments, modus operandi or certain project delivery and contract types (i.e. what kinds of projects these companies engage in). For example, in the largest companies, business models were related to practise, where processes were defined and described in terms of quality systems and/or along certain standards such as ISO. In addition, several interviewees thought it possible to express the business model with a quantitative measure (e.g. acceptable level of risk and return for certain kinds of projects).

\section{Value Creation and Capture}

The results of the interviews indicate that the managers in construction do not understand the concept of the business model in the way that it is depicted in the literature. Quite frankly, business models do not seem to play any significant role in developing and managing these companies, as the descriptions about how the concept is deployed differ quite a lot from a rigorous analysis of how a company creates value for selected markets as a system and how its parts support each other. In the managers' discourse, 'business model' is something that is used to define what kinds of initiatives they want to engage in. Referring to the most common business model elements, the managers' conception of the business model is limited to the revenue model. Even there, the focus is mainly on how the company creates value for itself - which is expressed in terms of return on investment or some similar measure - excluding the customer from the equation.

The business model descriptions in Table 1 clearly show the managers' difficulty in explaining the way their companies create value for their customers. Only a few of the interviewees could define who their customers were, who they were targeting and whom they wished to work with. In this regard, business model descriptions are limited to a few loosely-defined strategic choices, such as where companies want to operate geographically and what kind of projects (size, delivery type and field of operation) they want to engage in. Most of the companies, for example, aim for turnkey projects (i.e. through design-build delivery), but nobody was able to explain how their company's turnkey delivery differed from another. Instead, projects are executed as they are specified by the customer, meaning that executing projects 'according to customers' wishes' means creating value for them.

By using at least the most common elements of a business model - offering, value creation system and revenue model - managers in construction would have a language and framework to analyse and describe their businesses from a systems perspective. These key elements can be further specified if needed, but the key is to have a defined framework for designing and communicating business models. Currently, the lack of such a framework produces only partial descriptions, and subsequently, a partial understanding of business models with subjective and changing definitions. Current thinking does not consider alternative ways of value creation or specify exactly what kind of value a company is bringing to its clients' projects in order to create value in a way that others do not or cannot. In the

Pekuri, A et al (2013) 'The role of business models in Finnish construction companies', Australasian Journal of Construction Economics and Building, 13 (3) 13-23 
worst case, all of the companies interviewed focused on acquiring their next job from highly volatile local markets; in the best case, they attempted to gain complete responsibility for the project. Only a few companies referred to the unique value they were producing for some specific field of operation, which usually feature customers with specific characteristics.

\section{Competitive Advantage}

As already stated, it was hard to identify any unique sources of competitive advantage through the interviews. The few that we managed to identify related directly to resources or to doing something specific over a longer span of time, i.e. organisational learning. For example, one of the medium-sized companies owns a crane, which provides access to a variety of projects in the company's operating area and demonstrates the surprising fact that certain equipment may still create at least a temporary competitive advantage. Then, some companies have long been specialised in project management contracting or renovation construction, consequently building their competence in these specific areas. In addition, a proportion of back-office costs seems to be a distinguishing factor between small and large companies. Smaller companies have the cost advantage in smaller projects while larger companies have the financial resources to engage in more valuable projects. The importance of human resources was largely considered to be limited to supervisors, their suitability for certain types of projects and their ability to successfully steer projects. Construction workers were considered interchangeable.

In light of Barney's (1991) definition of sustainable competitive advantage, most of the aforementioned factors only create a temporary advantage because other firms can duplicate their benefits easily. It is also hard to consider the construction companies' activities as advantage-creating core competences which, according to Prahalad and Hamel (1990), represent the collective learning in the organisation, are characterised by the ability to provide access to a wide variety of markets and make a significant contribution to the perceived customer benefits while being difficult for competitors to imitate. Small companies' operating logics come closest to meeting all three requirements, but even these companies have to compete fiercely with other very similar companies, thus missing the requirement of being difficult to imitate. In fact, it is hard to know what extra value these companies could provide over others within the project delivery. Thus, it is understandable that customers often see price as the only distinctive factor between construction companies; hence the bidding wars

Analysing the behaviour of these companies through Porter's (1980) generic strategies unveils companies' identity crises. It is hard to find any strategy - cost leadership, differentiation, focus - that is being pursued in its purest form. For example, having awareness of lean construction and practising it actively would indicate that a company is pursuing cost leadership and trying to push the productivity frontier (see Porter 1996) ahead through advanced methods, but this is not the case for these companies. Instead, the focus is mostly on short-term cost-cutting during the projects. In addition, companies do not seem to be very differentiated from others as they mostly follow the standard procedures of the construction industry and, as can be seen from Table 2, all medium and large companies are too diversified to justify focus strategy. Interviewees thought that diversification is needed to protect companies from high market volatility, a belief observed by Junnonen (1998). This diversification means that local markets set limitations for growth and that companies expand their operating spheres to find both diversity and volume for their businesses. Yet, by utilising the business model concept and developing their value creation capabilities, construction companies could better define the exact value they are creating for their customers and how they differ from their competitors.

\section{Research Implications}

Compared to many other industries where the business model is often considered and implemented at the level of a firm or a business unit, such as manufacturing and e-business

Pekuri, A et al (2013) 'The role of business models in Finnish construction companies', Australasian Journal of Construction Economics and Building, 13 (3) 13-23 
(Hedman \& Kalling 2003; Morris et al. 2005; Tikkanen et al. 2005), the construction business is far too varied (meaning that the same company can build roads, mines, business premises and residential units) in nature for a similar approach to be exploited. Similarly, we thought that the use of project- or solution-level business models, as suggested by Kujala et al. (2010), would not be practical if the objective is to understand companies as systems that can be designed, managed and further developed using business models. Thus, we suggest that business models in the construction industry should be studied and developed at the level of field of operation. This would aid understanding value creation in different types of construction projects and developing business models that would better meet the needs of specific customers or market segments while also providing a competitive edge for construction companies. This level of analysis seems appropriate as in every field there are different customers and ways in which value is created and captured, hence justifying the claim that they should have their own business models. Currently, construction projects seem to be executed using a universal recipe that leaves both customers and businessman without satisfaction.

Figure 1 provides a conceptual model of our suggestion. The objective of the research and development function is to create business models that provide maximum value for certain customer segments, i.e. clients and users in specific fields of operation. At the core of these business models are offerings - the bundle of products and services that are valuable for customers. The project-delivery process incorporates many stages, from briefing to design and from purchasing to construction, realizing the offering and providing value to the customers. This process, which consists of the specific activities, resources and methods needed and used in project execution, should also be under constant development in order to fine tune the project delivery process for future projects. The last component, revenue model, defines the way a company captures value for itself from the project, i.e. makes money. In construction, this is usually dependent on the used contract where the fees and additional incentives are defined, but managers should still understand the differences between projects (e.g. the role of sales in B2C projects or fixed fees in B2B projects) and their implications for other parts of the system.

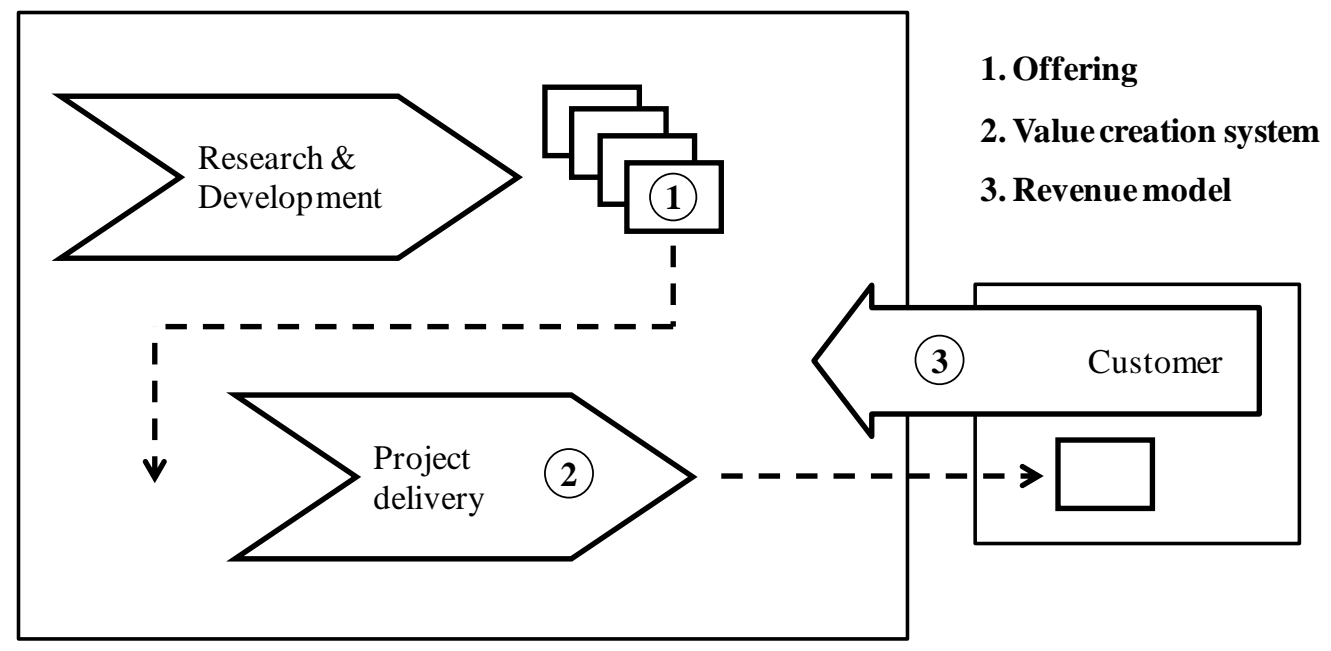

Figure 1 Interdependent business model elements in a process context

\section{Conclusions}

This paper focused on analysing managers' understanding of the business model concept and explored the business models currently used in Finnish construction companies. According to the results, managers in construction understand business models very differently than those in other sectors or within the academic literature. The main difference is that they relate these models to their companies' fields of operation, business segments, modus operandi, certain project delivery and contract types, financial objectives and 
securing more work. There seem to be as many definitions and purposes for business models as there are managers in construction. The results of the interviews indicate that the managers in construction do neither understand the concept properly nor exploit any similar value creation analysis in their business. The interviewees had significant problems describing their companies' business models and value creation logic, pointing out the lack of analysis and understanding of customer values and needs in the project delivery process. This may be one of the overtones of the persistent client dissatisfaction in the construction industry.

The limitations of the study are mostly concerned with the depth of interviews, sample size and the choice of companies. There were varying interpretations for the business model concept that may have affected how interviewers understood the operating logic of companies. One reason for this, perhaps, is that the interviewed managers were, due to their education and experience, more technically rather than business-oriented. This is, however, quite common in the construction industry and, thus, does not prove as a limitation of the study in itself/as such. Further, the local nature of construction markets may have unidentified consequences that would prevent further generalisation of the findings as the studied companies operate in rather small geographical area - Finland. However, the authors' general observation while studying the construction industry is that construction companies have nowhere near exploited the potential of business model innovation when making their businesses more profitable and sound. Thus both qualitative and quantitative research on business models is highly recommend in order to produce new information about the nature of business models in construction and their effectiveness from customers' and firm's perspective.

\section{References}

Afuah, A. (2003) 'Redefining firm boundaries in the face of the internet: are firms really shrinking?', The Academy of Management Review, 28 (1), 34-53.

Afuah, A., and Tucci, C. (2000) Internet Business Models and Strategies: Text and Cases, McGraw-Hill Higher Education, Boston, MA.

Barney, J.B. (1991) 'Firm resources and sustained competitive advantage', Journal of Management, 17 (1), 99-121.

Burkhart, T., Krumeich, J., Werth, D., and Loos, P. (2011) 'Analyzing the business model concept-a comprehensive classification of literature', in International Conference on Information Systems 2011 Proceedings, Shanghai, China.

Casadesus-Masanell, R., and Ricart, J. (2010) 'From strategy to business models and onto tactics', Long Range Planning, 43 (2/3), 195-215.

Casadesus-Masanell, R., and Ricart, J. (2011) 'How to design a winning business model', Harward Business Review, 89 (1/2), 100-107.

Chesbrough, H., and Rosenbloom, R.S. (2002) 'The role of the business model in capturing value from innovation: evidence from Xerox Corporation's technology spin-off companies', Industrial and Corporate Change, 11 (3), 529-555.

Hamel, G. (2000) Leading the revolution, Harvard Business School Press, Boston, MA.

Hedman, J., and Kalling, T. (2003) 'The business model concept: theoretical underpinnings and empirical illustrations', European Journal of Information Systems, 12 (1), 49-59.

Johnson, M., Christensen, C., and Kagermann, H. (2008) 'Reinventing your business model', Harvard Business Review, 86 (12), 51-59.

Junnonen, J.-M. (1998) 'Strategy formation in construction firms', Engineering, Construction and Architectural Management, 5 (2), 107-114.

Pekuri, A et al (2013) 'The role of business models in Finnish construction companies', Australasian Journal of Construction Economics and Building, 13 (3) 13-23 
Kujala, S., Artto, K., Aaltonen, P., and Turkulainen, V. (2010) 'Business models in projectbased firms - towards a typology of a solution-specific business models', International Journal of Project Management, 28 (2), 96-106.

Linder, J., and Cantrell, S. (2000) 'Changing business models: surveying the landscape', working paper, The Accenture Institute for Strategic Change, 24 May, available at: http://course.shufe.edu.cn/jpkc/zhanlue/upfiles/edit/201002/20100224120954.pdf (accessed 23 April 2013).

Magretta, J. (2002) 'Why business model matter', Harvard Business Review, 80 (5), 86-92.

Morris, M., and Schindehutte, M., and Allen, J. (2005) 'The entrepreneur's business model: toward a unified perspective', Journal of Business Research, 58 (6), 726-735.

Mutka, S., and Aaltonen, P. (2013) 'The impact of a delivery project's business model in a project-based firm', International Journal of Project Management, 31 (2), 166-176.

Nenonen, S., and Storbacka, K. (2010) 'Business model design: conceptualizing networked value co-creation', International Journal of Quality and Service Sciences, 2 (1), 43-59.

Osterwalder, A. (2004) The business model ontology - a proposition in design science approach, doctoral thesis, Department of Business and Economics, University of Lausanne, Switzerland.

Osterwalder, A., and Pigneur, Y. (2009) Business Model Generation, John Wiley \& Sons, New Jersey, NJ.

Pateli, A.G., and Giaglis, G.M. (2004) 'A research framework for ananysing eBusiness models', European Journal of Information Systems, 13 (4), 302-314.

Pekuri, A., Herrala, M., Haapasalo, H., and Pekuri, L. (forthcoming) 'Managing value creation: the business model approach in construction', International Journal of Business Innovation and Research.

Porter, M.E. (1980) Competitive Strategy. Free Press, New York.

Porter, M.E. (1985) Competitive Advantage: Creating and Sustaining Superior Performance. Free Press, New York.

Porter, M.E. (1996) 'What is strategy', Harvard Business Review, 74 (6), 61-78.

Prahalad, C.K., and Hamel, G. (1990) 'The core competences of the corporation', Harvard Business Review, 68 (3), 79-91.

Shafer, S., Smith, J., and Linder, J. (2005) 'The power of business models', Business Horizons, 48 (3), 199-207.

Stabell, C., and Fjeldstad, Ø. (1998) 'Configuring value for competitive advantage: on chains, shops, and networks', Strategic Management Journal, 19 (5), 413-437.

Suikki, R., Goman, A., and Haapasalo, H. (2006) 'A framework for creating business models - a challenge in convergence of high clock speed industry', International Journal of Business Environment, 1 (2), 211-233.

Teece, D. (2010) 'Business models, business strategy and innovation', Long Range Planning, 43 (2-3), 172-194.

Tikkanen, H., Lamberg, J.-A., Parvinen, P., and Kallunki, J.-P. (2005) 'Managerial cognition, action and the business model of the firm', Management Decision, 43 (5/6), 789-809.

Timmers, P. (1998) 'Business models for electronic markets', Electronic Markets, 8 (2), 3-8.

Zott, C., and Amit, R. (2007) 'Business model designs and the performance of entrepreneurial firms', Organization Science, 18 (2), 181-99.

Wikström, K., Artto, K., Kujala, J., and Söderlund, J. (2010) 'Business models in project business', International Journal of Project Management, 28 (8), 832-841. 